Michą JĘDRZEJCZYK*

\title{
WieloletNiE PLANOWANIE FINANSOWE NA SZCZEBLU UNII EUROPEJSKIEJ
}

\section{Wstęp}

Podstawowym celem badawczym niniejszego opracowania jest zaprezentowanie współczesnego obrazu planowania wieloletniego w Unii Europejskiej (UE). Autor stawia tezę, że w Polsce nie byłoby współczesnego obrazu planowania wieloletniego na poziomie budżetu państwa oraz jednostek samorządu terytorialnego, gdyby nie przystąpienie Polski do UE. Dlatego też, ze względu na wpływ przepisów prawa unijnego na obecnie stosowane w Polsce rozwiązania prawne dotyczące wzmocnienia dyscypliny finansowej, prognozowania i planowania wieloletniego, należało w publikacji dokonać analizy prawodawstwa i doktryny prawa pierwotnego i wtórnego UE. W tym celu rozważania prowadzone w artykule odnoszą się w sposób szczególny do Traktatu o funkcjonowaniu Unii Europejskiej, w którym podniesiono rangę planowania wieloletniego poprzez wprowadzenie specjalnego rozdziału poświęconego wieloletnim ramom finansowym ${ }^{1}$, a przez to potraktowania koncepcji planowania wieloletniego jako prawa traktatowego. Wprowadzone przepisy uregulowały podstawowe kwestie dotyczące ram finansowych - które przed wprowadzeniem traktatu nosiły nazwę perspektywy finansowej - doprecyzowując cele, dla których są przyjmowane, minimalny pięcioletni okres ich ustanawiania, obowiązku zachowania zgodności budżetu ogólnego

* Dr, Katolicki Uniwersytet Lubelski Jana Pawła II, radca prawny; e-mail: michaljedrzej@op.pl, ORCID ID: https:/ / orcid.org/0000-0001-7376-3904.

1 Traktat o funkcjonowaniu Unii Europejskiej (wersja skonsolidowana), Dz. Urz. UE C 326 z 26.10.2012, s. 47-200 (dalej: TFUE). 
z ramami finansowymi, a także formę prawną oraz ogólną strukturę wewnętrzną. Ponadto niezbędnym dla niniejszej pracy było odniesienie się do dyrektywy Rady z dnia 8 listopada 2011 r. ${ }^{2}$ w sprawie wymogów dla ram budżetowych państw członkowskich, która była elementem przyjętego pakietu legislacyjnego składającego się z sześciu aktów prawnych³, określanego też powszechnie jako tzw. „sześciopak”. Przyjmuje się, że to właśnie ta dyrektywa ustanowiła zasadę wieloletniego planowania budżetowego, która powinna mieć zastosowanie w procesie formułowania priorytetów polityki budżetowej wszystkich państw członkowskich UE. Podstawową metodą badawczą zastosowaną w artykule była metoda dogmatyczno-prawna, dzięki której - w oparciu o zasady wykładni prawa - dokonano analizy tekstów prawnych. Zgodnie z takim założeniem, analizy i oceny zostały sformułowane przy wykorzystaniu poglądów doktryny oraz nauki prawa finansowego.

\section{Planowanie finansowe $w$ okresie funkcjonowania Wspólnot Europejskich}

Planowanie finansowe w okresie funkcjonowania Wspólnot Europejskich, praktycznie do końca lat 80 . XX w., podlegało zasadom rocznego

2 Dyrektywa Rady 2011/85/UE z dnia 8 listopada 2011 r. w sprawie wymogów dla ram budżetowych państw członkowskich, Dz. Urz. UE L 306 z 23.11.2011, s. 41-47 (dalej: dyrektywa Rady 2011/85/UE).

3 Rozporządzenie Parlamentu Europejskiego i Rady (UE) nr 1173/2011 z dnia 16 listopada 2011 r. w sprawie skutecznego egzekwowania nadzoru budżetowego w strefie euro, Dz. Urz. EU L 306 z 23.11.2011, s. 1-7; rozporządzenie Parlamentu Europejskiego i Rady (UE) nr 1174/2011 z dnia 16 listopada 2011 r. w sprawie środków egzekwowania korekty nadmiernych zakłóceń równowagi makroekonomicznej w strefie euro, Dz. Urz. UE L 306 z 23.11.2011, s. 8-11; rozporządzenie Parlamentu Europejskiego i Rady (UE) nr 1175/2011 z dnia 16 listopada 2011 r. zmieniające rozporządzenie Rady (WE) nr 1466/97 w sprawie wzmocnienia nadzoru pozycji budżetowych oraz nadzoru i koordynacji polityk gospodarczych, Dz. Urz. UE L 306 z 23.11.2011, s. 12-24; rozporządzenie Parlamentu Europejskiego i Rady (UE) nr 1176/2011 z dnia 16 listopada 2011 r. w sprawie zapobiegania zakłóceniom równowagi makroekonomicznej i ich korygowania, Dz. Urz. UE L 306 z 23.11.2011, s. 25-32; rozporządzenie Rady (UE) nr 1177/2011 z dnia 8 listopada 2011 r. zmieniające rozporządzenie (WE) nr 1467/97 w sprawie przyspieszenia i wyjaśnienia procedury nadmiernego deficytu, Dz. Urz. UE L 306 z 23.11.2011, s. 33-40. 
planowania budżetowego. Podejmowane w latach 70. próby budżetowania wieloletniego realizowane były przez przyjmowanie trzyletnich prognoz finansowych, umożliwiających usytuowanie budżetu Wspólnot w ramach kilkuletniego planu finansowego. Dzięki przyjmowanym corocznie prognozom możliwe było także określenie następstw finansowych obowiązywania rozporządzeń i decyzji oraz propozycji przedstawionych Radzie przez Komisje ${ }^{4}$. Ponadto, pewne elementy instrumentów wieloletniego planowania finansowego, zawierały także kilkuletnie programy wspólnotowe, dotyczące finansowania określonych przedsięwzięć w ówczesnej Europejskiej Wspólnocie Gospodarczej i w państwach członkowskich ${ }^{5}$. Przykładem w tym zakresie może być rozporządzenie Rady z dnia 18 marca 1975 r., którym powołano Europejski Fundusz Rozwoju Regionalnego, wyposażając go jednocześnie w środki finansowe na trzy kolejne lata 6 .

Niemniej brakowało powiązania programów ze źródłami ich finansowania w perspektywie kilkuletniej, co powodowało, że każdorazowo $\mathrm{w}$ ramach rocznej procedury budżetowej, musiano zatwierdzać kwotę środków przeznaczoną na finansowanie danego programu w określonym roku ${ }^{7}$. Działanie takie doprowadziły do sporów kompetencyjnych pomiędzy Radą, a Parlamentem Europejskim w zakresie rozgraniczenia władzy legislacyjnej i władzy budżetowej. Samodzielne ustalanie wysokości limitów finansowych przez Radę dla programów wieloletnich powodowało bowiem, że uprawnienia Parlamentu Europejskiego, dotyczące procedury uchwalania budżetu rocznego, ograniczały się do automatycznego akceptowania kwot wcześniej ustalonych przez Radę .

Konieczność skoordynowania działań legislacyjnych i budżetowych oraz usprawnienia procedury przyjmowania budżetu rocznego

4 Decyzja Rady z dnia 21 kwietnia 1970 r. dotycząca kilkuletnich prognoz finansowych, Dz. Urz. WE L 94 z 28.04.1970, s. 23.

5 Rozporządzenie Rady (EWG) nr 724/75 z dnia 18 marca 1975 r. ustanawiające Europejski Fundusz Rozwoju Regionalnego, Dz. Urz. WE L 73 z 21.03.1975, s. 1-7.

6 Tamże.

7 Zob. M. Tyniewicki, Unia Europejska, [w:] E. Ruśkowski (red.), Roczność i wieloletniość w finansach publicznych, Warszawa 2014, s. 26.

8 Zob. D. Strasser, The Finances of Europe, Luxembourg 1992, s. 208, za: M. Tyniewicki, Unia Europejska, s. 26. 
spowodowało przyjęcie w dniu 30 czerwca 1982 r. ${ }^{9}$ przez Parlament, Radę i Komisję deklaracji przyjmowania porozumień międzyinstytucjonalnych, dotyczących wzmocnienia dyscypliny budżetowej i usprawnienia procedury budżetowej. Rozwiązanie takie umożliwiło określenie wysokości finansowania programów w perspektywie wieloletniej, którą ustalono na pięć lat, co z kolei skutkowało koniecznością tworzenia wieloletnich planów finansowych. Pierwsze $\mathrm{z}$ porozumień zostało zawarte $\mathrm{w}$ dniu 29 czerwca 1988 r. i jednocześnie zawierało pierwszy wieloletni plan finansowy na lata 1988-1992, określany mianem perspektywy finansowej ${ }^{10}$. Przyjęcie w 1988 r. wieloletniej perspektywy finansowej uznawane jest za preludium sformalizowanego planowania finansowego w dzisiejszej Unii Europejskiej, pomimo że do końca 2009 r. planowanie takie znajdowało się poza ramami traktatowymi ${ }^{11}$. Warto podkreślić, że w związku z reformami systemu finansowego Europejskiej Wspólnoty Gospodarczej, wynikającymi z II pakietu Delorsa ${ }^{12}$, kolejne perspektywy finansowe przyjmowane były na okresy siedmioletnie ${ }^{13}$.

Wraz z wejściem w życie Traktatu o funkcjonowaniu Unii Europejskiej podniesiono range planowania wieloletniego, poprzez wprowadzenie

9 Joint Declaration of the European Parliament, the Council and the Commission of 30 June 1982 on Various Measures to Improve the Budgetary Procedure, Dz. Urz. WE C 194 z 28.07.1982, s. 1-38.

10 Interinstitutional Agreement on Budgetary Discipline and Improvement of the Budgetary Procedure, Dz. Urz. WE L 185 z 15.07.1998, s. 33 za: M. Tyniewicki, Unia Europejska, [w:] E. Ruśkowski (red.), Roczność i wieloletniość w finansach publicznych, Warszawa 2014, s. 27.

11 Zob. M. Tyniewicki, Unia Europejska, s. 26.

12 Zob. European Commission, European Union Public Finance, Luxembourg 2008, s. 51.

13 Perspektywa finansowa 1993-1999 zawarta w porozumieniu międzyinstytucjonalnym z dnia 29 października 1993 r. (Intereinstitutional Agrement of the 29 October 1993 on Budgetary Discipline and Improvement of the Budgetary Procedure, Dz. Urz. WE C 331 z 7.12.1993, s. 1-10); perspektywa finansowa 2000-2006 zawarta w porozumieniu międzyinstytucjonalnym z dnia 6 maja 1999 r. (porozumienie międzyinstytucjonalne z dnia 6 maja 1999 r. między Parlamentem Europejskim, Radą oraz Komisją w sprawie dyscypliny budżetowej i poprawy procedury budżetowej, Dz. Urz. WE C 172 z 18.06.1999, s. 1-22 z późn. zm.); perspektywa finansowa 2007-2013 zawarta w porozumieniu międzyinstytucjonalnym z dnia 17 maja 2006 r. (porozumienie międzyinstytucjonalne z dnia 17 maja 2006 r. między Parlamentem Europejskim, Radą oraz Komisją w sprawie dyscypliny budżetowej i należytego zarządzania finansami, Dz. Urz. UE C 139 z 14.06.2006, s. 1-17 z późn. zm.). 
specjalnego rozdziału poświęconego „Wieloletnim ramom finansowym” ${ }^{14}$, a przez to potraktowania koncepcji planowania wieloletniego jako prawa traktatowego. Wprowadzone przepisy uregulowały podstawowe kwestie dotyczące ram finansowych doprecyzowując cele, dla których są przyjmowane, minimalny pięcioletni okres ich ustanawiania, obowiązku zachowania zgodności budżetu ogólnego z ramami finansowymi, a także formę prawną oraz ogólną strukturę wewnętrzną.

Dodatkowo należy wskazać, że zgodnie z uregulowaniami traktatowymi zerwano z wcześniejszą praktyką przyjmowania wieloletnich ram finansowych w porozumieniach międzyinstytucjonalnych i wprowadzono zasadę ustanawiania kolejnych wieloletnich ram finansowych (poczynając od obecnie obowiązujących na lata $2014-2020^{15}$ ) na podstawie rozporządzenia Rady.

W obecnym stanie prawnym wieloletnie ramy finansowe są siedmioletnim planem finansowym UE, który zgodnie z TFUE ${ }^{16}$, ma zapewnić dokonywanie wydatków Unii w sposób usystematyzowany i w granicach jej zasobów własnych w przyjętym, przynajmniej pięcioletnim, okresem rozliczeniowym. Ponadto wieloletnie ramy finansowe stanowiąc swoisty program wieloletni mają za zadanie przedkładać priorytety polityczne UE nad wielkości budżetowe, a zarazem stanowić instrument dyscypliny i planowania budżetowego. Jak podkreśla się w literaturze przedmiotu, przy konstrukcji wieloletnich ram finansowych wykorzystuje się przede wszystkim zasady ekonomiczne i organizacyjno-funkcjonalne. W pierwszym bowiem przypadku ustalenie wydatków, w ujęciu wieloletnim, zwiększa stabilność budżetu, ponieważ otrzymujący środki są $\mathrm{w}$ stanie przewidzieć poziom tych wydatków w kolejnych latach. Natomiast $\mathrm{w}$ drugim przypadku, zasady o charakterze organizacyjno-funkcjonalnym powodują lepszą współpracę między instytucjami zaangażowanymi co roku w przyjmowanie budżetu ${ }^{17}$.

14 Zob. art. 312 TFUE.

15 Rozporządzenie Rady (UE, Euratom) nr 1311/2013 z dnia 2 grudnia 2013 r. określające wieloletnie ramy finansowe na lata 2014-2020, Dz. Urz. UE L 347 z 15.12.2012, s. 884-891 (dalej: rozporządzenie Rady (UE, Euratom) nr 1311/2013 z dnia 2 grudnia 2013 r.).

16 Zob. art. 312 TFUE.

17 Zob. K. Piotrowska-Marczak, Konsekwencje zróżnicowania zadań publicznych w systemie planowania wieloletniego, [w:] K. Piotrowska-Marczak, T. Uryszek (red.), Zarzadzanie finansami publicznymi, Warszawa 2009, s. 176. 


\section{Nałożenie na kraje członkowskie Unii Europejskiej obowiązku wieloletniego planowania finansowego}

Należy się zgodzić z powszechnie głoszonym stanowiskiem, że do 2011 r. UE nie podejmowała formalnych działań, które zobowiązywałyby kraje członkowskie do opracowywania wieloletnich planów finansowych związanych z ich kondycją finansową ${ }^{18}$.

Dopiero wraz z nadejściem kryzysu gospodarczego, objawiającego się głównie wzrostem deficytów i długów publicznych państw członkowskich należących do strefy euro, ponad limity przyjęte $\mathrm{w}$ procedurze unikania nadmiernego deficytu będącego częścią TFUE ${ }^{19}$, spowodowało konieczność intensyfikacji działań. W dużej mierze czynności te ukierunkowane zostały na rzecz wypracowania instrumentów planowania wieloletniego, które byłyby w stanie w przyszłości zapobiegać takim zjawiskom. W tym aspekcie należy podkreślić, że procedura unikania nadmiernego deficytu, której uszczegółowienie znalazło się $\mathrm{w}$ protokole $\mathrm{nr} 12^{20}$ do Traktatu o funkcjonowaniu Unii Europejskiej, polegała głównie na wprowadzeniu do systemu dwóch wartości odniesienia (3\% PKB w przypadku deficytu oraz 60\% PKB w przypadku długu publicznego). Przekroczenie wskazanych limitów powodowało konieczność opracowania przez Komisję Europejską sprawozdania - opiniowanego następnie przez Komitet Ekonomiczno-Finansowy - mającego na celu zweryfikowanie zaobserwowanych przekroczeń, a w przypadku ich potwierdzenia, przesłania informacji do państwa członkowskiego i Rady. Ostatecznie Rada mogła zdecydować o nałożeniu procedury nadmiernego deficytu budżetowego $\mathrm{z}$ nakazaniem niezwłocznego usunięcia takiego naruszenia.

W tym zakresie warto podkreślić, że już od początku istnienia Unii Gospodarczej i Walutowej, część z państw przyjmujących walutę euro, nie spełniała kryteriów fiskalnych zawartych w Traktacie o Unii

18 Zob. tamże, s. 177.

19 Odpowiednio 3\% dla stosunku planowanego lub rzeczywistego deficytu publicznego do produktu krajowego brutto wyrażonego w cenach rynkowych oraz $60 \%$ dla stosunku zadłużenia publicznego do produktu krajowego brutto wyrażonego w cenach rynkowych (art. 1 protokołu nr $12 \mathrm{w}$ sprawie procedury dotyczącej nadmiernego deficytu będącego częścią TFUE).

20 Protokół (nr 12) w sprawie Procedury dotyczącej nadmiernego deficytu, Dz. Urz. UE C 83 z 30.03.2010, s. 279. 
Europejskiej z 1992 r. Tytułem przykładu można wskazać, że w 1997 r. kryterium długu publicznego nie spełniała: Grecja (108,7\% PKB), Włochy (121,6\% PKB), Belgia (122,2\% PKB $)^{21}$. Przyjęte wówczas założenie, że ze względu na stabilną pozycję gospodarek państw tworzących Unię Gospodarczą i Walutową, problem nadmiernego zadłużenia się określonych państw ma charakter przejściowy - okazało się błędne. Państwa, które wówczas miały problem z kryterium długu publicznego, do dziś stoją na granicy wypłacalności ${ }^{22}$. W tym kontekście warto podkreślić, że tylko w latach 2012-2013, dług publiczny w niektórych krajach członkowskich przekroczył nawet kilkakrotnie maksymalny poziom zadłużenia ${ }^{23}$.

Sposobem na wzmocnienie przyjętych w Traktacie z Maastricht reguł fiskalnych okazać się miało przyjęcie w 1997 r. tzw. Pakietu Stabilności i Wzrostu, na którego składały się cztery akty prawne ${ }^{24}$. Należy zaznaczyć, że pod względem prawnym, tylko rozporządzenia Rady miały charakter powszechnie wiążący dla państw członkowskich.

Pierwsze z wymienionych rozporządzeń nr 1466/97/WE z dnia 7 lipca 1997 r. miało na celu wzmocnienie nadzoru pozycji budżetowych oraz koordynację polityki gospodarczej. Ponadto regulacja ta wymagała, aby

21 Zob. K. Marchewka-Bartkowiak, Pakt na rzecz stabilności wzrostu, „Infos” 2011, nr 4, s. 1-2.

${ }^{22}$ Zob. L. Oręziak, Doświadczenia krajów strefy euro w zwalczaniu deficytów budżetowych, "Bank i Kredyt" 2004, nr 8, s. 18 i nast.

23 Grecja - 156\% i 175,2\% PKB; Irlandia - 117,6\% i 123,3\% PKB; Włochy - 127,0\% i 131,4\%, Portugalia - 126,6\% i 123,0\% PKB, dane pochodzą z European Commission, Report on Public Finance in EMU 2013, European Economy 4, [Brussels] 2013, s. 19.

${ }^{24}$ Rezolucja Rady Europejskiej z dnia 17 czerwca 1997 r. w sprawie Paktu Stabilności i Wzrostu, Dz. Urz. WE C 236 z 2.08.1997, s. 1-2; rezolucja Rady Europejskiej z dnia 16 czerwca 1997 r. w sprawie wzrostu i zatrudnienia, Dz. Urz. WE C 236 z 2.08.1997, s. 3-4; rozporządzenie Rady (WE) nr 1466/97/WE z dnia 7 lipca 1997 r. w sprawie wzmocnienia rozpoznania sytuacji budżetowych oraz rozpoznania i koordynacji polityk gospodarczych, Dz. Urz. WE L 209 z 2.08.1997, s. 1-5; Dz. Urz. UE polskie wyd. spec.: rozdz. 10, t. 1, s. 84 z późn. zm. (dalej: rozporządzenie Rady (WE) nr 1466/97/WE z dnia 7 lipca 1997 r.); rozporządzenie Rady (WE) nr 1467/97 z dnia 7 lipca 1997 r. w sprawie przyśpieszenia i wyjaśnienia stosowania procedury nadmiernego deficytu, Dz. Urz. WE L 209 z 2.08.1997, s. 6-11; Dz. Urz. UE polskie wyd. spec.: rozdz. 10, t. 1, s. 89 (dalej: rozporządzenie Rady (WE) nr 1467/97 z dnia 7 lipca 1997 r.). 
państwa członkowskie ze strefy euro przygotowywały programy stabilności ${ }^{25}$, zaś państwa spoza strefy - programy zbieżności ${ }^{26}$.

Wprowadzenie konieczności przygotowywania wskazanych programów dawało Radzie możliwość sprawowania nadzoru nad państwami członkowskimi w zakresie prowadzonej przez nie polityki gospodarczej, a tym samym dawało szanse wczesnego ostrzegania wystąpienia nadmiernego deficytu. Warto podkreślić, że przygotowywane programy - odpowiednio stabilności dla państw ze strefy euro oraz zbieżności dla państw spoza strefy euro - miały obowiązek prezentować dane dotyczące m.in.:

- średniookresowego celu budżetowego oraz ścieżkę dostosowywania deficytu lub nadwyżki do wybranego celu,

- przewidywanego rozwoju ogólnego wskaźnika zadłużenia,

- podstawowych założeń dotyczących spodziewanego rozwoju sytuacji gospodarczej (wydatki państwa na inwestycje, wzrost produktu krajowego brutto w ujęciu realnym (PKB), poziom zatrudnienia i inflacja),

- opisu środków podejmowanych w ramach polityki budżetowej oraz ocenę jej wpływu na budżet w ujęciu ilościowym,

- analizy, w jaki sposób zmiany głównych założeń ekonomicznych mogłyby wpłynąć na pozycję budżetu i zadłużenia,

- prognozy stosunku nadwyżki/deficytu płatniczego oraz wskaźnika zadłużenia i głównych założeń ekonomicznych przedkładanej raz w roku i obejmującej, oprócz roku bieżącego i ubiegłego, przynajmniej trzy następne lata ${ }^{27}$.

Natomiast rozporządzenie Rady (WE) nr 1467/97/WE z 7 lipca 1997 r. miało na celu przyspieszenie i wyjaśnienie procedury nadmiernego deficytu, a przez to hamowanie nadmiernych deficytów sektora instytucji rządowych i samorządowych oraz dążenie do niezwłocznego wyeliminowania zaistniałych przekroczeń deficytu i długu publicznego ${ }^{28}$. Środki dyscyplinujące, jakie mogły być zastosowane, uzależniono od tego czy dany kraj wchodził do strefy euro oraz czy zamierzał współpracować z Komisją i Radą w zakresie szybkiego usunięcia stwierdzonych naruszeń. Do

${ }_{25}$ Zob. pkt 8 preambuły rozporządzenia Rady (WE) nr 1466/97/WE z dnia 7 lipca 1997 r.

${ }^{26}$ Zob. pkt 9 preambuły rozporządzenia Rady (WE) nr 1466/97/WE z dnia 7 lipca 1997 r.

27 Zob. art. 3 rozporządzenia Rady (WE) nr 1466/97/WE z dnia 7 lipca 1997 r.

28 Zob. art. 1 rozporządzenia Rady (WE) nr 1467/97/WE z dnia 7 lipca 1997 r. 
środków dyscyplinujących, jakie można było zastosować w przypadku stwierdzenia nadmiernego deficytu, należało zaliczyć m.in.:

- zalecenie Rady podjęcia przez dane państwo członkowskie w nieprzekraczalnym terminie czterech miesięcy skutecznych działań mających na celu obniżenie nadmiernego deficytu oraz zaplanowania takich samych działań na kolejny rok od stwierdzenia nadmiernego deficytu ${ }^{29}$,

- podanie przez Radę do publicznej wiadomości jej zaleceń w przypadku stwierdzenia, że nie zostały podjęte żadne skuteczne działania redukcji deficytu przez państwo członkowskie objęte procedurą nadmiernego deficytu ${ }^{30}$,

- wezwanie państwa członkowskiego do przyjęcia w wyznaczonym terminie środków zmierzających do takiego ograniczenia deficytu, jakie Rada uzna za niezbędne ${ }^{31}$,

- zastosowanie lub, w odpowiednim przypadku, wzmocnienie jednego lub kilku środków wynikających z Traktatu o funkcjonowaniu Unii Europejskiej w tym m.in.:

- opublikowanie przez państwo członkowskie dodatkowych informacji, które określi Rada, przed emisją obligacji i papierów wartościowych,

- wezwanie Europejskiego Banku Inwestycyjnego do ponownego rozważenia polityki udzielania pożyczek wobec danego państwa członkowskiego,

- zażądanie złożenia w Unii przez dane państwo członkowskie nieoprocentowanego depozytu o stosowanej wysokości aż do czasu, gdy, w ocenie Rady, nadmierny deficyt zostanie skorygowany,

- nałożenie grzywny w stosownej wysokości ${ }^{32}$.

Niemniej ułomność tak zaprezentowanego programu stabilności i wzrostu została potwierdzona przez samych twórców systemu tj. Francję i Niemcy, które nie spełniając wymogów stawianych przez pakt, nie poniosły z tego tytułu żadnych konsekwencji, pomimo że nie podjęły żadnych skutecznych działań, mających na celu redukcję deficytu ${ }^{33}$.

29 Zob. art. 3 ust. 4 rozporządzenia Rady (WE) nr 1467/97/WE z dnia 7 lipca 1997 r.

30 Zob. art. 4 ust. 1 rozporządzenia Rady (WE) nr 1467/97/WE z dnia 7 lipca 1997 r.

31 Zob. art. 6 rozporządzenia Rady (WE) nr 1467/97/WE z dnia 7 lipca 1997 r.

32 Zob. art. 126 ust. 11 TFUE.

33 Zob. L. Oręziak, Reforma Paktu Stabilności i Wzrostu i jej potencjalne konsekwencje, „Bank i Kredyt” 2005, nr 7, s. 16. 
Kolejną próbą wzmocnienia nadzoru procesu budżetowania w państwach członkowskich była nowelizacja przyjętych w 1997 r., opisanych wyżej, rozporządzeń. Zgodnie z rozporządzeniem Rady (WE) z dnia 27 czerwca 2005 r. ${ }^{34}$ dla państw, które przyjęły walutę euro oraz państw uczestniczących w ERM2 (Exchange Rate Mechanism) wyznaczono przedział między -1\% PKB, a równowagą lub nadwyżką w ujęciu uwzględniającym zmiany cykliczne, po skorygowaniu o środki jednorazowe i tymczasowe, w którym powinien zmieścić się średniookresowy cel budżetowy. Natomiast rozporządzenie Rady (WE) z dnia 27 czerwca 2005 r., przyjęło za najważniejszą potrzebę niezwłocznego skorygowania deficytu oraz zredefiniowania wyjątkowego przekroczenia wartości w następstwie znacznego pogorszenia się koniunktury. Zgodnie z wprowadzonymi zmianami, za wyjątkowe przekroczenie wartości odniesienia, Komisja mogła odtąd uznać sytuację, będącą następstwem ujemnego rocznego tempa wzrostu PKB lub skumulowanego spadu produkcji, podczas przedłużającego się okresu bardzo niskiego wzrostu PKB w stosunku do potencjalnego wzrostu ${ }^{35}$.

Niemniej, pomimo że instrumenty mające przeciwdziałać nadmiernej nierównowadze i zadłużeniu, w tym procedura nadmiernego deficytu oraz Pakt Stabilności i Wzrostu, były na przestrzeni lat modyfikowane i udoskonalane, okazały się na tyle nieskuteczne, że koniecznym było podjęcie dodatkowych działań mających na celu wzmocnienie nadzoru budżetowego także w stosunku do państw spoza strefy euro ${ }^{36}$.

W dalszym ciągu widoczna była zatem potrzeba wzmocnienia koordynacji polityk budżetowych oraz wprowadzenie procedur monitorowania, zapobiegania i korygowania zakłóceń równowagi makroekonomicznej w państwach członkowskich ${ }^{37}$. W tym zakresie zdecydowano się na uchwalenie w dniu 8 listopada 2011 dyrektywy Rady 2011/85/UE

34 Rozporządzenie Rady (WE) nr 1055/2005 z dnia 27 czerwca 2005 r. zmieniające rozporządzenie (WE) nr 1466/97 w sprawie wzmocnienia nadzoru pozycji budżetowych oraz nadzoru i koordynacji polityk gospodarczych, Dz. Urz. UE L 174 z 7.07.2005, s. 1-4.

35 Zob. A. Kargol-Wasiluk, Procedura nadmiernego deficytu budżetowego w Unii Europejskiej - próba oceny sytuacji w Polsce, [w:] J. Szołno-Koguc, A. Pomorska (red.), Ekonomiczne i prawne uwarunkowania i bariery deficytu i dtugu publicznego, Warszawa 2011, s. 87-88.

36 Zob. P.J. Lewkowicz, M. Tyniewicki, Ocena unijnych $i$ krajowych regulacji prawnych ograniczających dtug publiczny, [w:] H. Litwińczuk (red.), Prawo europejskie 5 lat doświadczeń w polskim prawie finansowym, Warszawa 2011, s. 73.

37 Zob. M. Tyniewicki, Unia Europejska, s. 18. 
w sprawie wymogów dla ram budżetowych państw członkowskich, która była elementem przyjętego pakietu legislacyjnego składającego się z sześciu aktów prawnych, określanego też jako tzw. „sześciopak”38. Na marginesie należy jedynie podkreślić, że wzmocnienie nadzoru budżetowego przebiegało bardziej intensywnie w krajach, które przyjęły wspólną walutę euro, dla których w 2013 r. uchwalono dodatkowe dwa akty prawne ${ }^{39}$.

Na podstawie wprowadzonych przepisów został nałożony na państwa członkowskie obowiązek wprowadzenia do ich systemów prawnych reguł wieloletniego planowania budżetowego ${ }^{40} \mathrm{w}$ postaci konstruowania średniookresowych ram budżetowych zapewniających realizację celów ustalonych na szczeblu UE ${ }^{41}$. Należy zaznaczyć, że średniookresowe ramy budżetowe, przyjmowane przez państwa członkowskie, stanowiły zbiór krajowych procedur budżetowych, wydłużających perspektywę

38 Rozporządzenie Parlamentu Europejskiego i Rady (UE) nr 1173/2011 z dnia 16 listopada 2011 r. w sprawie skutecznego egzekwowania nadzoru budżetowego w strefie euro; rozporządzenie Parlamentu Europejskiego i Rady (UE) nr 1174/2011 z dnia 16 listopada 2011 r. w sprawie środków egzekwowania korekty nadmiernych zakłóceń równowagi makroekonomicznej w strefie euro; rozporządzenie Parlamentu Europejskiego i Rady (UE) nr 1175/2011 z dnia 16 listopada 2011 r. zmieniające rozporządzenie Rady (WE) nr 1466/97 w sprawie wzmocnienia nadzoru pozycji budżetowych oraz nadzoru i koordynacji polityk gospodarczych; rozporządzenie Parlamentu Europejskiego i Rady (UE) nr 1176/2011 z dnia 16 listopada 2011 r. w sprawie zapobiegania zakłóceniom równowagi makroekonomicznej i ich korygowania; rozporządzenie Rady (UE) nr 1177/2011 z dnia 8 listopada 2011 r. zmieniające rozporządzenie (WE) nr 1467/97 w sprawie przyspieszenia i wyjaśnienia procedury nadmiernego deficytu; dyrektywa Rady 2011/85/UE z dnia 8 listopada 2011 r. w sprawie wymogów dla ram budżetowych państw członkowskich.

39 Rozporządzenie Parlamentu Europejskiego i Rady (UE) nr 473/2013 z dnia 21 maja 2013 r. w sprawie wspólnych przepisów dotyczących monitorowania i oceny projektów planów budżetowych oraz zapewnienia korekty nadmiernego deficytu w państwach członkowskich należących do strefy euro, Dz. Urz. UE L 140 z 27.05.2013, s. 11-23; rozporządzenie Parlamentu Europejskiego i Rady (UE) nr 472/2013 z dnia 21 maja 2013 r. w sprawie wzmocnienia nadzoru gospodarczego i budżetowego nad państwami członkowskimi należącymi do strefy euro dotkniętymi lub zagrożonymi poważnymi trudnościami w odniesieniu do ich stabilności finansowej, Dz. Urz. UE L 140 z 27.05.2013, s. 1-10.

40 Zob. M. Tyniewicki, Dyrektywa Rady 2011/85/UE z dnia 8 listopada 2011 r. w sprawie wymogów dla ram budżetowych państw członkowskich - jej rola w upowszechnianiu zasady wieloletniości w finansach publicznych oraz problemy interpretacyjne i praktyczne, [w:] E. Ruśkowski (red.), Roczność i wieloletniość w finansach publicznych, Warszawa 2014, s. 249.

${ }^{41}$ Komisja Europejska, Wniosek dyrektywa Rady w sprawie wymogów dotyczących ram budżetowych w państwach członkowskich z dnia 29 września 2010 r. [uzasadnienie do projektu], $\operatorname{KOM(2010)} 523$ wersja ostateczna, s. 7, EUR-Lex. 
kształtowania polityki budżetowej poza coroczny cykl budżetowy, w tym ustalały priorytety politycznych i średniookresowych celów budżeto$w_{y c h}{ }^{42}$. Przykładowe elementy, które składały się na ramy budżetowe, zostały określone poprzez konieczność wprowadzenia m.in.:

- systemu rachunkowości budżetowej i sprawozdawczości statystycznej,

- reguł i procedur regulujących przygotowanie prognoz na potrzeby planowania wyników budżetowych,

- uzgodnień dotyczących monitorowania i analizy w celu zwiększenia przejrzystości elementów procesu budżetowego,

- mechanizmów i zasad regulujących relacje budżetowe pomiędzy organami publicznymi we wszystkich podsektorach finansów publicznych ${ }^{43}$.

Ponadto wprowadzenie przedmiotowej regulacji wymagało, aby standardy w konstruowaniu ram budżetowych przez państwa członkowskie obejmowały przede wszystkim:

- minimalny trzyletni okres planowania budżetowego ${ }^{44}$,

- niezmienność kursu polityki budżetowej, w oparciu o który procedury są konstruowane ${ }^{45}$,

- zachowanie wiarygodności, realistyczności oraz przejrzystości danych będących podstawą planowania wieloletniego ${ }^{46}$,

- odpowiednią ocenę danych wykorzystywanych na potrzeby planowania budżetowego ${ }^{47}$,

- zgodność rocznej ustawy budżetowej z treścią ram budżetowych ${ }^{48}$,

- konsolidacyjny charakter wieloletniego planowania finansowego ${ }^{49}$.

Ostatecznie wprowadzenie średniookresowych ram budżetowych spowodowało wydłużenie perspektywy kształtowania polityki budżetowej poza roczny cykl budżetowy, w tym umożliwiło ustalenie politycznych priorytetów i średniookresowych celów budżetowych. Dlatego też przyjmuje się, że dyrektywa ta ustanowiła zasadę wieloletniego

${ }_{42}$ Zob. art. 2 lit. e dyrektywy Rady 2011/85/UE.

43 Zob. art. 9 dyrektywy Rady 2011/85/UE.

44 Zob. pkt 19 preambuły dyrektywy Rady 2011/85/UE.

45 Zob. pkt 21 preambuły i art. 9 ust 2 lit. c i d dyrektywy Rady 2011/85/UE.

${ }^{46}$ Zob. pkt 4, 8, 9 preambuły dyrektywy Rady 2011/85/UE.

47 Zob. art. 4 ust. 6 dyrektywy Rady 2011/85/UE.

48 Zob. art. 10 dyrektywy Rady 2011/85/UE.

49 Zob. art. 14 dyrektywy Rady 2011/85/UE. 
planowania budżetowego, która powinna mieć zastosowanie $\mathrm{w}$ procesie formułowania priorytetów polityki budżetowej państw członkowskich ${ }^{50}$.

Należy przy tym podkreślić, że powyższe zasady stanowiły jedynie minimum, które należało uwzględnić przy implementacji wskazanej dyrektywy, zaś państwa członkowskie upoważnione zostały do ustanawiania innych, dodatkowych regulacji odnoszących się do ich krajowych, wieloletnich planów finansowych.

Tak rozumiana konstrukcja planowania wieloletniego nawiązywała w konsekwencji do przyjętego w dyrektywie Rady uzasadnienia, zgodnie z którym, pomimo że:

coroczne uchwalanie ustawy budżetowej jest kluczowym elementem procesu budżetowego, $\mathrm{w}$ ramach którego $\mathrm{w}$ państwach członkowskich podejmowane są ważne decyzje budżetowe, to większość działań fiskalnych ma konsekwencje budżetowe znacznie wykraczające poza roczny cykl budżetowy ${ }^{51}$.

Ponadto wypada zaakcentować, że naruszenie standardów wynikających ze wspomnianego Paktu Stabilności, wymusiło podjęcie dodatkowych działań zmierzających do wzmocnienia zarządzania gospodarczego w UE. Dlatego też w dniu 2 marca 2012 r. doszło do podpisania przez państwa członkowskie Unii (z wyjątkiem Wielkiej Brytanii i Czech) Traktatu o stabilności, koordynacji i zarządzaniu w Unii Gospodarczej i Walutowej ${ }^{52}$ - określanego potocznie mianem Paktu Fiskalnego. Jednym z podstawowych zadań traktatu, oprócz ochrony stabilności strefy euro, była potrzeba zapewnienia „,zdrowych i stabilnych finansów publicznych

50 Zob. E. Ruśkowski i in., Roczność i wieloletniość w finansach publicznych - ewolucja rozwiązań UE i doświadczenia polskie, [w:] M. Lubińska, M. Będzieszak, N. Marska-Dzioba (red.), Zarzadzanie finansami publicznymi a efektywność, Warszawa 2015, s. 73.

51 Pkt 20 preambuły dyrektywy Rady 2011/85/UE z dnia 8 listopada 2011 r. w sprawie wymogów dla ram budżetowych państw członkowskich, Dz. Urz. UE. L 306 z 23.11.2011, s. 41-47.

52 Traktat o stabilności, koordynacji i zarządzaniu w Unii Gospodarczej i Walutowej pomiędzy Królestwem Belgii, Republiką Bułgarii, Królestwem Danii, Republiką Federalną Niemiec, Republiką Estońską, Irlandią, Republiką Grecką, Królestwem Hiszpanii, Republiką Francuską, Republiką Włoską, Republiką Cypryjską, Republiką Łotewską, Republiką Litewską, Wielkim Księstwem Luksemburga, Węgrami, Maltą, Królestwem Niderlandów, Republiką Austrii, Rzecząpospolitą Polską, Republiką Portugalską, Rumunią, Republiką Słowenii, Republiką Słowacką, Republiką Finlandii i Królestwem Szwecji, sporządzony w Brukseli dnia 2 marca 2012 r., Dz. U. z 2013 r. poz. 1253 (dalej: Trakt ustanawiający Europejski Mechanizm Stabilności). 
oraz konieczność unikania nadmiernego deficytu sektora instytucji rządowych i samorządowych" poprzez stosowanie „zasady zrównoważonego budżetu" ${ }^{23}$, polegającej na określeniu celów średniookresowych i ram czasowych ich osiągania. Dodatkowo celem traktatu było wdrożenie programu partnerstwa budżetowego i gospodarczego oraz zgodnych z nim rocznych planów budżetowych, a także objęcie wdrażania monitorowaniem na zasadach określonych w traktacie przez Komisję Europejską i Radę UE54. Pomimo, że dla Polski "Mechanizm Stabilności” - wynikający z traktatu - nie był obowiązkowy, to jednak w wyniku udzielonego przez Sejm upoważnienia dla Prezydenta Rzeczypospolitej Polskiej do ratyfikowania traktatu (z dnia 20 lutego 2013 r.) $)^{55}$ i samego aktu ratyfikacji (w dniu 27 lutego 2013 r.), umowa ta ostatecznie weszła w życie z dniem 1 września 2013 r. W ten sposób Polska, podobnie jak państwa ze strefy euro, zobowiązała się do wzmożonego monitorowania własnych finansów publicznych zwłaszcza w zakresie unikania nadmiernego deficytu sektora instytucji rządowych i samorządowych. Zaznaczyć jednak należy, że podobnie jak to miało miejsce $w$ przypadku swobody wyboru metod planowania wieloletniego w celu realizacji średniookresowych celów budżetowych, tak i w tym wypadku Polska mogła dążyć do zachowania stabilności finansów publicznych poprzez zastosowanie własnych koncepcji wieloletniego planowania finansowego, zarówno na szczeblu państwa, jak też jednostek samorządu terytorialnego.

Oczywiście należy stanowczo podkreślić, że roczna zasada planowania finansowego, będąca podstawą planowania gospodarczego w UE, nie oznaczała, że metoda ta stała w sprzeczności z planowaniem finansowym w ujęciu wieloletnim. Współczesne źródło rocznego cyklu planowania

53 Zob. art. 3 Traktu ustanawiającego Europejski Mechanizm Stabilności.

54 Zob. J. Stankiewicz, Wieloletnie planowanie finansowe państwa w Polsce na tle wybranych krajów europejskich, [w:] E. Ruśkowski (red.), Roczność i wieloletniość w finansach publicznych, Warszawa 2014, s. 214.

55 Ustawa z dnia 20 lutego 2013 r. o ratyfikacji Traktatu o stabilności, koordynacji i zarządzaniu w Unii Gospodarczej i Walutowej pomiędzy Królestwem Belgii, Republiką Bułgarii, Królestwem Danii, Republiką Federalną Niemiec, Republiką Estońską, Irlandią, Republiką Grecką, Królestwem Hiszpanii, Republiką Francuską, Republiką Włoską, Republiką Cypryjską, Republiką Łotewską, Republiką Litewską, Wielkim Księstwem Luksemburga, Węgrami, Maltą, Królestwem Niderlandów, Republiką Austrii, Rzecząpospolitą Polską, Republiką Portugalską, Rumunią, Republiką Słowenii, Republiką Słowacką, Republiką Finlandii i Królestwem Szwecji, sporządzonego w Brukseli dnia 2 marca 2012 r., Dz. U. z 2013 r. poz. 283. 
finansowego w UE odnaleźć można w Traktacie o funkcjonowaniu Unii Europejskiej ${ }^{56}$ oraz $\mathrm{w}$ rozporządzeniu ${ }^{57}$, zgodnie z którymi:

- wszystkie dochody i wydatki Unii powinny stanowić przedmiot preliminarza na każdy rok budżetowy i być wpisane do budżetu,

- długość roku jest określona przez pryzmat roku kalendarzowego,

- realizacja budżetu po stronie wydatków odbywa się metodą kasową,

- niedokonanie wydatków zaplanowanych w budżecie rocznym wiąże się z utratą mocy autoryzacyjnej aktu budżetowego,

- wydatki dzielą się na zróżnicowane (obejmujące środki na płatności i zobowiązania) i niezróżnicowane (wydatki o charakterze bieżącym, np. administracyjne),

- zasada rocznego planowania wpisana jest do katalogu zasad budżetowych, zgodnie z którymi uchwala się i wykonuje budżet UE.

\section{Wnioski końcowe}

Aktualnie uważa się, że zasada rocznego planowania finansowego w Unii została jedynie udoskonalona o metody planowania wieloletniego. Zgodnie z treścią rozporządzenia Rady (UE, Euratom) nr 1311/2013 z dnia 2 grudnia 2013 r. Parlament Europejski, Rada i Komisja, podczas każdej procedury budżetowej oraz przy wykonywaniu budżetu na dany rok, zachowują zgodność z rocznymi pułapami wydatków, określonymi w ramach wieloletnich ram finansowych. Oznacza to, że kolejno uchwalane budżety roczne, jako plany szczegółowe wpisują się w wieloletnie ramy finansowe, które jednocześnie stają się planem finansowym ogólnym i siedmioletnim. Równoczesne funkcjonowanie koncepcji roczności planowania budżetowego, wyrażającego się w uchwalaniu rocznych budżetów z wieloletniością wynikającą z wieloletnich ram finansowych, stanowi dopełnienie kompleksowego prowadzenia gospodarki finansowej oraz kompleksowości

56 Zob. art. 310, 312, 313 TFUE.

57 Rozporządzenie Parlamentu Europejskiego i Rady (UE, Euratom) z dnia 25 października 2012 r. nr 966/2012 w sprawie zasad finansowych mających zastosowanie do budżetu ogólnego Unii oraz uchylające rozporządzenie Rady (WE, Euratom) nr 1605/2002, Dz. Urz. UE L 298 z 26.10.2012, s. 1-96. 
planowania finansowego. Dzięki takiemu rozwiązaniu istnieje możliwość oparcia gospodarki finansowej o perspektywę krótkoterminową - roczną oraz długoterminową - wykraczającą poza rok budżetowy ${ }^{58}$.

Odtąd w celu uwzględnienia wieloletniej perspektywy budżetowej, zakładanej w unijnych ramach nadzoru budżetowego, podstawą planowania uchwalanej co roku ustawy budżetowej, powinno być wieloletnie planowanie budżetowe wynikające ze średniookresowych ram budżetowych ${ }^{59}$. Dlatego też, w procesach projektowania i zarządzania własnymi finansami publicznymi, każde państwo członkowskie winno kierować się nie tylko perspektywą krótkookresową (roczną), ale przede wszystkim powinno mieć na uwadze okres wykraczający poza roczny cykl budżetowy. Innymi słowy, podstawą tych procesów powinna być wieloletniość, tak samo jak powinna być ona podstawą uchwalanej co roku ustawy budżetowej ${ }^{60}$.

Dlatego też stwierdzić należy, że zmiana w podejściu do idei planowania finansowego podyktowana była nie tylko impulsem niedawnych wydarzeń gospodarczych, które przyniosły nowe wyzwania, a którym polityka budżetowa w Unii musiała stawić czoła ${ }^{61}$, lecz była wynikiem wieloletnich działań podejmowanych najpierw przez Wspólnotę, a następnie przez UE w celu uzupełnienia zasady roczności budżetu o koncepcje prowadzenia gospodarki finansowej w układzie planowania wieloletniego.

Należy podkreślić, że termin transpozycji obowiązku wprowadzenia średniookresowych ram budżetowych oraz wzmocnienia zasady wieloletniości do krajowych porządków prawnych państw członkowskich ustalony został do dnia 31 grudnia 2013 r., co skutkowało tym, że przepisy krajowe wprowadzające postanowienia dyrektywy w życie ostatecznie miały zacząć obowiązywać od stycznia 2014 r. ${ }^{62}$

Polską odpowiedzią na konieczność wprowadzenia średniookresowych ram budżetowych na poziomie budżetu państwa był wieloletni plan finansowy państwa, zaś w jednostkach samorządu terytorialnego wieloletnia prognoza finansowa. Oba rozwiązania zostały uregulowane w ustawie o finansach publicznych. Należy jednak zaznaczyć, że w Polsce

58 Zob. M. Tyniewicki, Unia Europejska, s. 39.

59 Zob. pkt 20 preambuły dyrektywy Rady 2011/85/UE.

60 Zob. tamże.

${ }_{61}$ Zob. pkt 1 preambuły dyrektywy Rady 2011/85/UE.

62 Zob. art. 15 dyrektywy Rady 2011/85/UE. 
po 1990 r., podejmowane były już próby odbudowy znaczenia wieloletniości finansów publicznych.

Słowa kluczowe: wieloletnie planowanie finansowe, ramy budżetowe, Unia Europejska

\section{Bibliografia}

\section{Źródła}

\section{Akty prawne}

Ustawa z dnia 20 lutego 2013 r. o ratyfikacji Traktatu o stabilności, koordynacji i zarządzaniu w Unii Gospodarczej i Walutowej pomiędzy Królestwem Belgii, Republiką Bułgarii, Królestwem Danii, Republiką Federalną Niemiec, Republiką Estońską, Irlandią, Republiką Grecką, Królestwem Hiszpanii, Republiką Francuską, Republiką Włoską, Republiką Cypryjską, Republiką Łotewską, Republiką Litewską, Wielkim Księstwem Luksemburga, Węgrami, Maltą, Królestwem Niderlandów, Republiką Austrii, Rzecząpospolitą Polską, Republiką Portugalską, Rumunią, Republiką Słowenii, Republiką Słowacką, Republiką Finlandii i Królestwem Szwecji, sporządzonego w Brukseli dnia 2 marca 2012 r., Dz. U. z 2013 r. poz. 283.

Traktat o stabilności, koordynacji i zarządzaniu w Unii Gospodarczej i Walutowej pomiędzy Królestwem Belgii, Republiką Bułgarii, Królestwem Danii, Republiką Federalną Niemiec, Republiką Estońską, Irlandią, Republiką Grecką, Królestwem Hiszpanii, Republiką Francuską, Republiką Włoską, Republiką Cypryjską, Republiką Łotewską, Republiką Litewską, Wielkim Księstwem Luksemburga, Węgrami, Maltą, Królestwem Niderlandów, Republiką Austrii, Rzecząpospolitą Polską, Republiką Portugalską, Rumunią, Republiką Słowenii, Republiką Słowacką, Republiką Finlandii i Królestwem Szwecji, sporządzony w Brukseli dnia 2 marca 2012, Dz. U. z 2013 r. poz. 1253.

Traktat o funkcjonowaniu Unii Europejskiej (wersja skonsolidowana), Dz. Urz. UE C 326 z 26.10.2012, s. 47-200.

Rozporządzenie Rady (EWG) nr 724/75 z dnia 18 marca 1975 r. ustanawiające Europejski Fundusz Rozwoju Regionalnego [Regulation (EEC) No 724/75 of the Council of 18 March 1975 Establishing a European Regional Development Fund], Dz. Urz. WE L 73 z 21.03.1975, s. 1-7.

Rozporządzenie Rady (WE) nr 1466/97/WE z dnia 7 lipca 1997 r. w sprawie wzmocnienia rozpoznania sytuacji budżetowych oraz rozpoznania 
i koordynacji polityk gospodarczych [Council Regulation (EC) No 1466/97 of 7 July 1997 on the Strengthening of the Surveillance of Budgetary Positions and the Surveillance and Coordination of Economic Policies], Dz. Urz. WE L 209 z 2.08.1997, s. 1-5.

Rozporządzenie Rady (WE) nr 1467/97 z dnia 7 lipca 1997 r., w sprawie przyśpieszenia i wyjaśnienia stosowania procedury nadmiernego deficytu [Council Regulation (EC) No 1467/97 of 7 July 1997 on Speeding up and Clarifying the Implementation of the Excessive Deficit Procedure], Dz. Urz. WE L 209 z 2.08.1997, s. 6-11.

Rozporządzenie Rady (WE) nr 1055/2005 z dnia 27 czerwca 2005 r. zmieniające rozporządzenie (WE) nr 1466/97 w sprawie wzmocnienia nadzoru pozycji budżetowych oraz nadzoru i koordynacji polityk gospodarczych, Dz. Urz. UE L 174 z 7.07.2005, s. 1-4.

Rozporządzenie Rady (UE) nr 1177/2011 z dnia 8 listopada 2011 r. zmieniające rozporządzenie (WE) nr 1467/97 w sprawie przyspieszenia i wyjaśnienia procedury nadmiernego deficytu, Dz. Urz. UE L 306 z 23.11.2011, s. 33-40.

Rozporządzenie Parlamentu Europejskiego i Rady (UE) nr 1173/2011 z dnia 16 listopada 2011 r. w sprawie skutecznego egzekwowania nadzoru budżetowego w strefie euro, Dz. Urz. UE L 306 z 23.11.2011, s. 1-7.

Rozporządzenie Parlamentu Europejskiego i Rady (UE) nr 1174/2011 z dnia 16 listopada 2011 r. w sprawie środków egzekwowania korekty nadmiernych zakłóceń równowagi makroekonomicznej w strefie euro, Dz. Urz. UE L 306 z 23.11.2011, s. 8-11.

Rozporządzenie Parlamentu Europejskiego i Rady (UE) nr 1175/2011 z dnia 16 listopada 2011 r. zmieniające rozporządzenie Rady (WE) nr 1466/97 w sprawie wzmocnienia nadzoru pozycji budżetowych oraz nadzoru i koordynacji polityk gospodarczych, Dz. Urz. UE L 306 z 23.11.2011, s. 12-24.

Rozporządzenie Parlamentu Europejskiego i Rady (UE) nr 1176/2011 z dnia 16 listopada 2011 r. w sprawie zapobiegania zakłóceniom równowagi makroekonomicznej i ich korygowania, Dz. Urz. UE L 306 z 23.11.2011, s. 25-32.

Rozporządzenie Parlamentu Europejskiego i Rady (UE, Euratom) z dnia 25 października 2012 r. nr 966/2012 w sprawie zasad finansowych mających zastosowanie do budżetu ogólnego Unii oraz uchylające rozporządzenie Rady (WE, Euratom) nr 1605/2002, Dz. Urz. UE L 298 z 26.10.2012, s. 1-96.

Rozporządzenie Parlamentu Europejskiego i Rady (UE) nr 472/2013 z dnia 21 maja 2013 r. w sprawie wzmocnienia nadzoru gospodarczego i budżetowego nad państwami członkowskimi należącymi do strefy euro dotkniętymi lub zagrożonymi poważnymi trudnościami w odniesieniu do ich stabilności finansowej, Dz. Urz. UE L 140 z 27.05.2013, s. 1-10.

Rozporządzenie Parlamentu Europejskiego i Rady (UE) nr 473/2013 z dnia 21 maja 2013 r. w sprawie wspólnych przepisów dotyczących monitorowania 
i oceny projektów planów budżetowych oraz zapewnienia korekty nadmiernego deficytu w państwach członkowskich należących do strefy euro, Dz. Urz. UE L 140 z 27.05.2013, s. 11-23.

Rozporządzenie Rady (UE, Euratom) nr 1311/2013 z dnia 2 grudnia 2013 r. określające wieloletnie ramy finansowe na lata 2014-2020, Dz. Urz. UE L 347 z 15.12.2012, s. 884-891.

Rezolucja Rady Europejskiej z dnia 16 czerwca 1997 r. w sprawie wzrostu i zatrudnienia [Resolution of the European Council on Growth and Employment Pact Amsterdam], Dz. Urz. WE C 236 z 2.08.1997, s. 3-4.

Rezolucja Rady Europejskiej z dnia 17 czerwca 1997 r. w sprawie Paktu Stabilności i Wzrostu [Resolution of the European Council on the Stability and Growth Pact Amsterdam], Dz. Urz. WE C 236 z 2.08.1997, s. 1-2.

Dyrektywa Rady 2011/85/UE z dnia 8 listopada 2011 r. w sprawie wymogów dla ram budżetowych państw członkowskich, Dz. Urz. UE L 306 z 23.11.2011, s. $41-47$.

Protokół (nr 12) w sprawie procedury dotyczącej nadmiernego deficytu, Dz. Urz. UE C 83 z 30.03.2010.

Decyzja Rady z dnia 21 kwietnia 1970 r. dotycząca kilkuletnich prognoz finansowych, Dz. Urz. WE L 94 z 28.04.1970, s. 23; Dz. Urz. WE polskie wyd. spec.: rozdz. 1 , t. 1 , s. 46.

Joint Declaration of the European Parliament, the Council and the Commission of 30 June 1982 on Various Measures to Improve the Budgetary Procedure, Dz. Urz. WE C 194 z 28.07.1982, s. 1-38.

Interinstitutional Agrement of the 29 October 1993 on Budgetary Discipline and Improvement of the Budgetary Procedure, Dz. Urz. WE C 331 z 7.12.1993, s. 1-10.

Interinstitutional Agreement on Budgetary Discipline and Improvement of the Budgetary Procedure, Dz. Urz. WE L 185 z 15.07.1998.

Porozumienie międzyinstytucjonalne z dnia 6 maja 1999 r. między Parlamentem Europejskim, Radą oraz Komisją w sprawie dyscypliny budżetowej i poprawy procedury budżetowej [Interinstitutional Agreement of 6 May 1999 between the European Parliament, the Council and the Commission on Budgetary Discipline and Improvement of the Budgetary Procedure], Dz. Urz. WE C 172 z 18.06.1999, s. 1-22 z późn. zm.

Porozumienie międzyinstytucjonalne z dnia 17 maja 2006 r. między Parlamentem Europejskim, Radą oraz Komisją w sprawie dyscypliny budżetowej i należytego zarządzania finansami, Dz. Urz. UE C 139 z 14.06.2006, s. 1-17 z późn. zm.

Komisja Europejska, Wniosek dyrektywa Rady w sprawie wymogów dotyczących ram budżetowych w państwach członkowskich z dnia 29 września 2010 r. [uzasadnienie do projektu], $\mathrm{KOM}(2010) 523$ wersja ostateczna, s. 7, EUR-Lex. 


\section{Literatura}

Europen Commision, European Union Public Finance, Luxembourg 2008.

European Commission, Report on Public Finance in EMU 2013, European Economy 4, [Brussels] 2013.

Kargol-Wasiluk A., Procedura nadmiernego deficytu budżetowego w Unii Europejskiej - próba oceny sytuacji w Polsce, [w:] J. Szołno-Koguc, A. Pomorska (red.), Ekonomiczne i prawne uwarunkowania i bariery deficytu i długu publicznego, Warszawa 2011.

Lewkowicz P.J., M. Tyniewicki, Ocena unijnych i krajowych regulacji prawnych ograniczajacych dtug publiczny, [w:] H. Litwińczuk (red.), Prawo europejskie 5 lat doświadczeń w polskim prawie finansowym, Warszawa 2011.

Marchewka-Bartkowiak K., Pakt na rzecz stabilności wzrostu, "Infos” 2011, nr 4.

Oręziak L., Doświadczenia krajów strefy euro w zwalczaniu deficytów budżetowych, „Bank i Kredyt” 2004, nr 8.

Oręziak L., Reforma Paktu Stabilności i Wzrostu i jej potencjalne konsekwencje, „Bank i Kredyt" 2005, nr 7.

Piotrowska-Marczak K., Konsekwencje zróżnicowania zadań publicznych w systemie planowania wieloletniego, [w:] K. Piotrowska-Marczak, T. Uryszek (red.), Zarzadzanie finansami publicznymi, Warszawa 2009.

Ruśkowski E. i in., Roczność i wieloletniość w finansach publicznych-ewolucja rozwiqzań UE i doświadczenia polskie, [w:] M. Lubińska, M. Będzieszak, N. Marska-Dzioba (red.), Zarządzanie finansami publicznymi a efektywność, Warszawa 2015.

Stankiewicz J., Wieloletnie planowanie finansowe państwa w Polsce na tle wybranych krajów europejskich, [w:] E. Ruśkowski (red.), Roczność i wieloletniość w finansach publicznych, Warszawa 2014.

Strasser D., The Finances of Europe, Luxembourg 1992.

Tyniewicki M., Dyrektywa Rady 2011/85/UE z dnia 8 listopada 2011 r. w sprawie wymogów dla ram budżetowych państw członkowskich - jej rola w upowszechnianiu zasady wieloletniości w finansach publicznych oraz problemy interpretacyjne i praktyczne, [w:] E. Ruśkowski (red.), Roczność i wieloletniość w finansach publicznych, Warszawa 2014.

Tyniewicki M., Unia Europejska, [w:] E. Ruśkowski (red.), Roczność i wieloletniość w finansach publicznych, Warszawa 2014. 


\section{MULTI-ANNUAL FINANCIAL PLANNING AT THE EUROPEAN UNION LEVEL}

\section{Summary}

The main goal of the article is to present the concept of financial and evolution planning departing from the principle of annual budget planning in force during the period of the European Communities in favour of the concept of long-term financial planning of the European Union up to its final elevation to the law of the treaty. The considerations in the study focus on demonstrating that the contemporary image of long-term planning in the European Union is the result of a huge effort (especially political) and the creation of appropriate conditions to see the benefits of multi-annual planning. At the same time, the author emphasises that the interest in legislation and the doctrine concerning the primary and secondary European Union law results from the fact that European law is affected by the legal solutions currently in use in Poland, strengthening financial discipline, forecasting and long-term planning. In the author's opinion, the necessity to adjust the Polish budgeting system to the multi-annual financial planning has resulted from the need to integrate with the other EU countries and the established common structural policy in order to achieve the goals and directions of development set out by it. The article has been divided into four parts: introduction, financial planning during the European Communities' operations, imposition of the multi-annual financial planning on the EU Member States, and conclusions. The basic research method used in the article has been the dogmatic and legal method thanks to which legal texts were analysed based on the principles of legal interpretation. According to this assumption, the analyses and assessments have been formulated using the views of the doctrine and the science of financial law.

Key words: multi-annual financial planning, budgetary framework, European Union

\section{МНОГОЛЕТНЕЕ ФИНАНСОВОЕ ПЛАНИРОВАНИЕ НА УРОВНЕ ЕВРОПЕЙСКОГО СОЮЗА}

\section{Резюме}

Основная цель статьи - представить концепцию финансового планирования и эволюционный отход от принципа планирования годового бюджета, действовавшего в период функционирования Европейских сообществ, - в пользу концепции долгосрочного финансового планирования Европейского союза - вплоть до его окончательного возведения в ранг 
договорного права. Представленные в исследовании решения направлены на то, чтобы продемонстрировать, что современная картина многолетнего планирования в Европейском союзе является результатом огромных усилий (особенно политических) и создания соответствующих условий, позволяющих увидеть преимущества многолетнего планирования. В то же время автор подчеркивает, что интерес к законодательству и доктрине в отношении первичного и вторичного права Европейского союза обусловлен тем фактом, что законодательство Европейского союза влияет на правовые решения, используемые в настоящее время Польшей в отношении укрепления финансовой дисциплины, прогнозирования и многолетнего планирования. По мнению автора, целесообразность адаптации польской бюджетной системы к многолетнему финансовому планированию обусловлена необходимостью вписаться в модель экономической и пространственной унификации с другими странами ЕС, а также установленной общей структурной политики для достижения обозначенных ею целей и направлений развития. Статья разделена на четыре части: введение, финансовое планирование в период функционирования Европейских сообществ, наложение на государства-члены ЕС обязательства по многолетнему финансовому планированию и заключение. Основным методом исследования, использованным в статье, был юридико-догматический, благодаря которому, на основе принципов правовой интерпретации, проанализированы правовые тексты. Соответственно результаты анализа и оценки были сформулированы с использованием положений доктрины и науки финансового права.

Ключевые слова: многолетнее финансовое планирование, бюджетные рамки, Европейский союз 